\title{
FAKTOR PENYEBAB KECENDERUNGAN FRAUD PADA SEKTOR PUBLIK DI KOTA MAKASSAR
}

\author{
Andi Lutfi ${ }^{1}$, Prawira Aditiya Dzulfadeln ${ }^{2}$ \\ ${ }^{1}$ STIE Tri Dharma Nusantara \\ alutfi13@gmail.com \\ ${ }^{2}$ STIE Tri Dharma Nusantara
}

\begin{abstract}
This study aims to obtain empirical evidence regarding the factors causing the tendency of cheating in public sector organizations in Makassar City. The variables tested are distributive justice, procedural justice, internal control systems, leadership style and organizational ethical culture. The sample used in this research is 83 samples who work in the public sector in the city of Makassar. The sample was selected from several public sector agencies using convenience sample technique. Hypothesis testing uses the SEM (Structural Equations Model) analysis tool to test the indicators that form the constructs and examine the influence of variables that affect the tendency of cheating. The results showed the influence of procedural justice, internal control systems and leadership styles on the tendency to cheat.
\end{abstract}

Keywords: Fraud; tendency; public sector

\begin{abstract}
ABSTRAK
Penelitian ini bertujuan untuk memperoleh bukti empiris mengenai faktor penyebab kecenderungan kecurangan pada organisasi sektor publik di Kota Makassar. Variabel yang diuji yaitu keadilan distributif, keadilan prosedural, sistem pengendalian internal, gaya kepemimpinan dan budaya etis organisasi. Sampel yang digunakan dalam penelitian ini sebanyak 83 sampel yang bekerja di sektor publik di kota Makassar. Sampel diseleksi dari beberapa instansi sektor publik dengan teknik convenience sample. Pengujian hipotesis menggunakan alat analisis SEM (Structural equations model) untuk menguji indikator yang membentuk konstruk dan menguji pengaruh variabel yang mempengaruhi kecenderungan kecurangan. Hasil penelitian menunjukkan adanya pengaruh keadilan prosedural, sistem pengendalian internal dan gaya kepemimpinan terhadap kecenderungan kecurangan.
\end{abstract}

Kata kunci: Fraud; kecenderungan; sektor publik 


\section{PENDAHULUAN}

Salah satu bentuk fraud dalam sektor pemerintahan adalah korupsi. Korupsi merupakan kecurangan yang sering ditemukan di sektor pemerintahan. Tindakan fraud yang biasa dilakukan diantaranya melakukan manipulasi pencatatan, menghilangkan dokumen dan mark up. Indonesia Corruption Watch (ICW) mengungkapkan data korupsi tahun 2019. Terdapat 271 kasus korupsi dengan 580 tersangka yang menyebabkan kerugian negara sebesar Rp. 8,04 Triliun. Korupsi banyak melibatkan kepala daerah serta menteri dalam bentuk suap dan gratifikasi.

Setiap tahun kasus korupsi semakin meningkat melalui berbagai modus. Korupsi yang paling banyak digunakan oleh pelaku adalah penyalagunaan anggaran. Modus kedua dengan cara penggelembungan harga (mark up) dan pungutan liar serta suap dan gratifikasi. Bahkan apabila dilihat dari sisi besarnya anggaran, anggaran desa adalah objek yang paling banyak melibatkan pelaku korupsi kemudian sektor pemerintahan dan pendidikan. Berdasarkan data Indonesia Corruption Watch (ICW), provinsi yang memiliki kasus korupsi paling banyak adalah jawa timur dengan kerugian negara sebesar mencapai Rp. 90,2 Miliar. Korupsi juga banyak terjadi disaat aparat menerima uang untuk mempercepat proses pelayanan publik atau memungut uang terhadap pelayanan yang seharusnya gratis bahkan tidak memerlukan biaya. Kasus seperti ini sangat sering terjadi pada berbagai layanan sektor publik di Indonesia. Hal ini tentunya sangat merugikan bagi masyarakat yang menggunakan pelayanan sektor publik. Di satu sisi mempercepat dan mendahulukan pelayanan tapi di sisi lain tentunya merugikan pengguna layanan yang sudah mengantri lebih dulu. (Setiawan et al., 2016).

Salah satu model diperkenalkan oleh (Cressey, 1953) yaitu model Fraud Triangle. Model ini menjelaskan alasan seseorang melakukan fraud. Cressey tertarik pada embezzlers yang disebutnya sebagai "trust violators" atau para pelanggar kepercayaan. Trust violators yakni seseorang yang melanggar kepercayaan atau amanah yang dititipkan kepada mereka. Teori Fraud Triangle yang dikembangkan oleh (Cressey, 1953), mengatakan bahwa kecurangan disebabkan oleh tiga faktor, yang terdiri dari tekanan (Pressure), peluang (Opportunity), dan rasionalitas (Rationalization). 
Allen dan hamilton (1999) internal, gaya kepemimpinan dan budaya menunjukkan bahwa Indonesia memiliki indeks good governance paling rendah dan tingkat korupsi yang paling tinggi dibandingkan dengan beberapa negara di Asia tenggara. Kemudian (Wilopo, 2006) menyebutkan berbagai faktor-faktor penyebab terjadinya kecurangan akuntansi yaitu pengendalian internal, kompensasi, ketaatan pada aturan akuntansi, asimetri informasi, moralitas manajemen, terhadap perilaku tidak etis dan kecenderungan kecurangan akuntansi. Selain itu (Betts, 2009) menunjukkan berbagai alasan seseorang melakukan fraud dari sisi psikologis dan demografis di Amerika. Hasilnya menunjukkan pelaku kecurangan berpendidikan S1 dan S2 dengan usia 4050 tahun.

Penelitian (Pramudita, 2013), analisis fraud di sektor pemerintahan di Kota Salatiga menunjukkan bahwa terdapat pengaruh negatif antara keefektifan sistem pengendalian internal, kesesuaian kompensasi, budaya etis organisasi, gaya kepemimpinan terhadap fraud di sektor pemerintahan namun tidak ada pengaruh antara komitmen organisasi dan penegakan hukum terhadap fraud di sektor pemerintahan. Penelitian ini menguji pengaruh keadilan distributif, keadilan prosedural, sistem pengendalian etis organisasi terhadap kecenderungan kecurangan akuntasi yaitu.

\section{TELAAH LITERATUR DAN PENGEMBANGAN HIPOTESIS}

\section{Teori dan Hipotesis}

Teori atribusi (P. Robbins, 2003) menjelaskan bahwa manusia menilai orang lain dengan berbagai cara, tergantung pada makna yang dihubungkan ke suatu perilaku tertentu yang ditunjukkan. Pada dasarnya teori ini mengungkapkan bahwa jika seseorang mengamati perilaku seseorang individu, orang tersebut akan berusaha menentukan apakah perilaku itu disebabkan oleh faktor internal atau eksternal. Teori atribusi menjelaskan tentang bagaimana seseorang mencoba memahami peristiwa di sekitar mereka, dengan mengetahui alasan atas suatu kejadian yang mereka alami. Dispositional attributions atau penyebab internal merupakan aspek perilaku individual yang ada dalam diri seseorang seperti sifat, persepsi diri, kemampuan, motivasi. Sedangkan situational attributions atau penyebab eksternal berupa lingkungan sekitar yang mempengaruhi perilaku, seperti kondisi sosial, nilai-nilai sosial, dan pandangan masyarakat. Sehingga, setiap tindakan 
atau ide yang akan dilakukan seseorang akan dipengaruhi oleh faktor internal dan eksternal.

Fraud Triangle Theory atau teori segitiga kecurangan banyak digunakan untuk menjelaskan penyebab terjadinya fraud. Dalam teori segitiga kecurangan, terdapat model segitiga kecurangan untuk menjawab pertanyaan, mengapa orang melakukan kecurangan, atau mengapa kecurangan terjadi. Dalam teori ini (Cressey, 1953) menjelaskan bahwa kecurangan umumnya terdiri dari tiga sifat yaitu kesempatan (Opportunity), tekanan (Pressure), dan rasionalisasi (Rationalization).

Selanjutnya (Cressey, 1953) menyimpulkan bahwa orang yang dipercaya dapat menjadi pelanggar kepercayaan ketika ia melihat dirinya sendiri sebagai orang yang memiliki masalah keuangan yang tidak diceritakan kepada orang lain, seseorang tersebut sadar bahwa masalah ini akan dapat diatasinya dengan menyalahgunakan kewenangannya sebagai pemegang kepercayaan di bidang keuangan. Menurut Gbegi dan Adebisi (2015), Fraud sebagai istilah generik dan mencakup semua sarana dengan berbagai kecerdikan manusia yang dirancang oleh satu individu untuk mendapatkan keuntungan lebih dari yang lain dengan menggunakan keterangan palsu. Association of Certified Fraud Examiners (ACFE) (2008) menggunakan istilah "occupational fraud and abuse" dan mendefenisikannya sebagai penggunaan kedudukan seseorang untuk memperkaya diri sendiri melalui penyalahgunaan yang disengaja atau penyalahgunaan sumber daya atau aset organisasi. Occupational tree memiliki tiga jenis, yakni fraudulent statements, asset misappropriation dan corruption.

\section{Keadilan distributif}

Pada awal perkembangan teori dan penelitian keadilan organisasional, berfokus pada keadilan distributif. Keadilan berfokus pada perasaan dan perilaku orang dalam interaksi sosial yang berasal dari penilaian-penilaian keadilan atas hasil yang mereka peroleh ketika bertransaksi dengan pihak lain. Perhatian utama penelitian pada teori ketidakadilan (inequity theory) dijelaskan (Adams, 1965 dalam (Schminke et al., 1997)) dengan menunjukkan peran keadilan distributif yang sangat dominan mendapat dukungan yang luas. Selanjutnya (Walster et al., 1978) menunjukkan bahwa orang akan merasa paling terpuaskan ketika hasil yang mereka peroleh terdistribusi secara adil (Tyler \& Blader, 2003). 
Secara konseptual keadilan distributif berkaitan dengan distribusi keadaan dan barang yang akan berpengaruh terhadap kesejahteraan individu. Kesejahteraan tersebut meliputi aspek-aspek fisik, psikologis, ekonomi, dan sosial. Penelitian keadilan distributif dalam organisasi saat ini memfokuskan terutama pada persepsi seseorang terhadap adil tidaknya outcome yang mereka terima, yaitu penilaian mereka terhadap kondisi akhir dari proses alokasi (Palupi, 2012).

(Rawls, 2009) merumuskan dua prinsip keadilan distributif, sebagai berikut:

a. The greatest equal principle, bahwa setiap orang harus memiliki hak yang sama atas kebebasan dasar yang paling luas, seluas kebebasan yang sama bagi semua orang. Ini merupakan hal yang paling mendasar (hak azasi) yang harus dimiliki semua orang.

b. Ketidaksamaan sosial dan ekonomi harus diatur sedemikian rupa sehingga perlu diperhatikan azas atau prinsip berikut: the different principle, dan the principle of fair equality of opportunity. Prinsip ini diharapkan memberikan keuntungan terbesar bagi orang-orang yang kurang beruntung, serta memberikan penegasan bahwa dengan kondisi dan kesempatan yang sama, semua posisi dan jabatan harus terbuka bagi semua orang (Prinsip Perbedaan Obyektif). Prinsip kedua, yaitu "the different principle" dan "the principle of (fair) equality of opportunity", menurut penulis merupakan "prinsip perbedaan obyektif", artinya prinsip kedua tersebut menjamin terwujudnya proporsionalitas pertukaran hak dan kewajiban para pihak, sehingga secara wajar (obyektif) diterima adanya perbedaan pertukaran asalkan memenuhi syarat good faith and fairness (redelijkheid en billijkheid).

\section{H1:Keadilan distributif berpengaruh} negatif terhadap kecenderungan kecurangan di sektor publik.

\section{Keadilan prosedural}

Menurut (Greenberg \& Baron, 2003) keadilan prosedural didefinisikan sebagai persepsi keadilan atas pembuatan berbagai keputusan dalam organisasi. Orang-orang di dalam organisasi sangat memperhatikan dalam pembuatan keputusan secara adil. Mereka menganggap organisasi dan karyawan akan sama-sama diuntungkan jika organisasi melaksanakan prosedur secara adil. Keadilan prosedural mengambarkan 
pertimbangan yang dibuat oleh karyawan mengenai keadilan yang dipersepsikan dari proses dan prosedur organisasi yang digunakan untuk membuat keputusan alokasi dan sumber daya (Ivancevich John et al., 2006). Beberapa penelitian menunjukkan bahwa keadilan tidak sekedar membandingkan input dan output tetapi dapat diidentifikasi bagaimana proses dan prosedur dalam penentuan suatu outcome (Palupi, 2012). Pengambilan keputusan yang tidak adil akan mendorong pegawai sektor publik untuk melakukan kecurangan.

H2: Keadilan prosedural berpengaruh negatif terhadap kecenderungan kecurangan (Fraud) di sektor publik.

\section{Sistem pengendalian internal}

Kemajuan pengendalian internal pemerintah di Indonesia ditandai dengan terbitnya Peraturan Pemerintah Nomor 60 tahun 2008 tentang Sistem Pengendalian Internal Pemerintah (SPIP). Sistem pengendalian internal merupakan proses yang integral pada tindakan dan kegiatan yang harus dilakukan secara terus menerus oleh pimpinan dan seluruh pegawai untuk memberikan keyakinan memadai atas tercapainya tujuan organisasi melalui kegiatan yang efektif dan efisien, keandalan pelaporan keuangan, pengamanan aset negara, serta ketaatan terhadap peraturan perundangundangan. Menurut (Wilopo, 2006) sistem pengendalian internal bagi sebuah organisasi penting untuk memberikan perlindungan bagi entitas terhadap kelemahan manusia serta untuk mengurangi kemungkinan kesalahan dan tindakan yang tidak sesuai dengan peraturan organisasi.

Sistem pengendalian internal merupakan proses yang dijalankan untuk memberikan keyakinan memadai untuk mencapai laporan keuangan yang andal, meningkatkan kepatuhan terhadap hukum, dan meningkatkan efektivitas dan efisiensi operasi organisasi. Sedangkan menurut (Puspasari \& Suwardi, 2012), pengendalian akuntansi adalah bagian dari sistem pengendalian internal, meliputi struktur organisasi, metode, dan ukuranukuran yang dikoordinasikan terutama untuk menjaga kekayaan organisasi serta mengecek ketelitian dan keandalan data akuntansi. Ketidakefektifan pengendalian internal akan membuka kesempatan atau peluang untuk melakukan kecurangan karena pegawai akan memanfaatkan ketidakefektifan pengendalian internal tersebut sebagai suatu titik lemah. Uraian diatas menunjukkan bahwa keefektifan pengendalian internal penting dalam untuk mencegah kecurangan. 


\section{H3: Sistem pengendalian internal berpengaruh negatif terhadap kecenderungan kecurangan (Fraud) di sektor publik.}

\section{Gaya kepemimpinan}

Lingkungan perusahaan yang lebih etis, karyawan akan cenderung untuk mengikuti peraturan perusahaan. Peraturan-peraturan tersebut akan mendorong karyawan berperilaku bermoral dan bisa diterima sehingga lingkungan etis, yang dibentuk oleh gaya kepemimpinan yang baik, akan berpengaruh terhadap kecenderungan kecurangan yang dilakukan karyawan. Menurut COSO (2004) lingkungan yang etis dari suatu organisasi terdiri dari aspek seperti gaya top manajemen dalam mencapai sasaran organisasi, nilai-nilai dan gaya manajemen atau kepemimpinanya. Untuk membentuk suatu lingkungan etis yang dapat mencegah fraud, diperlukan sosok seorang pemimpin yang baik dimata karyawan. Karyawan yang memiliki persepsi buruk kepada pimpinannya akan cenderung melakukan kecurangan. Dapat disimpulkan bahwa gaya kepemimpinan yang baik dapat menurunkan kecenderungan terjadinya fraud.
H4: Gaya kepemimpinan berpengaruh negatif terhadap kecenderungan kecurangan (Fraud) di sektor publik.

\section{Budaya etis organisasi}

Etika organisasi adalah pola sikap dan perilaku yang diharapkan dari setiap individu dan kelompok anggota organisasi yang secara keseluruhan akan membentuk budaya organisasi (organizational culture) yang sejalan dengan tujuan maupun filosofi organisasi yang bersangkutan. Menurut (Rae \& Subramaniam, 2008) pada lingkungan yang lebih etis, karyawan akan cenderung mengikuti aturan perusahaan dan peraturan karena perilakunya akan dapat diterima secara moral.

Budaya Organisasi merupakan pola dasar yang diterima oleh organisasi untuk bertindak dan memecahkan masalah, membentuk karyawan yang mampu beradaptasi dengan lingkungan dan mempersatukan orang-orang didalam organisasi. Sedangkan (P. Robbins, 2003) mendefinisikan budaya organisasi sebagai persepsi bersama yang dianut dan dipahami oleh anggota-anggota organisasi itu yang membedakan organisasi satu dengan lainnya. Hal ini merupakan satu dari karakteristik nilai organisasi. Persepsi terhadap budaya organisasi didasarkan 
pada kondisi-kondisi yang dialami yang rendah akan memiliki resiko seseorang dalam organisasinya, seperti kecurangan akuntansi yang tinggi. penghargaan, dukungan, serta perilaku Selanjutnya (Wilopo, 2006) menjelaskan yang diharapkan diperoleh di organisasi. bahwa perilaku tidak etis memberikan Budaya organisasi pada intinya pengaruh yang signifikan dan positif merupakan sebuah sistem dari nilai-nilai terhadap kecenderungan kecurangan yang bersifat umum. Adapun nilai-nilai personal mulai dikembangkan pada saat awal kehidupan, seperti halnya kepercayaan pada umumnya, tersusun dalam sistem hirarki dengan sifat-sifat yang dapat dijelaskan dan diukur, serta konsekuensi- konsekuensi perilaku yang dapat diamati. Untuk menjaga budaya etis perlu melibatkan orang-orang jujur; yang menaati kebijakan dan kode etik; mempertahankan kebijakan yang jelas dan efektif untuk menangani fraud serta memastikan bahwa manajemen puncak juga melakukannya.

Adanya pelaksanaan hukuman dan penghargaan (reward) yang konsisten memberikan nilai tambah bagi terciptanya suatu etika perilaku dan struktur organisasi yang kuat. Pegawai akan merasakan diperlakukan secara adil dan merasa bersyukur atas posisi yang telah direraihnya jika etika organisasi dapat ditegakan secara konsisten oleh manajemen. Menurut CIMA dalam (Wilopo, 2006) berpendapat bahwa budaya perusahaan dengan standar etika (fraud) pada perusahaan.

Berdasarkan uraian diatas dapat disimpulkan bahwa budaya etis organisasi merupakan suatu gambaran dari perilaku manajemen yang dapat dicontoh dan ditiru oleh para pegawainya. Meskipun itu merupakan tindakan kecurangan (fraud) pegawai akan melakukan suatu pembenaran atas tindakannya tersebut karena merasa bahwa tindakannya itu sudah dengan tindakan yang dilakukan oleh manajemen. Kesimpulannya, budaya etis manajemen yang baik sangat berpengaruh terhadap kinerja pegawainya dan dapat menurunkan tindakan kecurangan (fraud).

H5: Budaya etis organisasi berpengaruh negatif terhadap kecenderungan kecurangan (Fraud) di sektor pemerintahan.

\section{METODE PENELITIAN}

\section{Populasi dan Sampel}

Sektor publik adalah sektor ekonomi yang menyediakan berbagai 
layanan pemerintah kepada masyarakat. Populasi pada penelitian ini adalah karyawan yang bekerja di puskesmas dan rumah sakit di Kota Makassar. Penentuan sampel menggunakan teknik convenience sampling. Sampel dalam penelitian ini sebanyak 83 pegawai yang bekerja disektor publik.

\section{Metode Pengumpulan Data}

Pengumpulan data dilakukan dengan cara menyebarkan kuisioner pada beberapa lembaga sektor publik di kota Makassar. Kuisioner disebarkan pada beberapa Rumah sakit, Kantor dinas, Perguruan tinggi, Kantor BUMN. Cara pengumpulan data dengan menggunakan media google formulir secara elektronik. Untuk memastikan bahwa kuisioner disebarkan kepada pegawai sektor publik, peneliti membatasi jumlah kuisioner yang disebar yaitu 15 kuisioner pada tiap-tiap kantor dengan bantuan pegawai tiap-tiap kantor yang membantu menyebarkan. Penelitian ini tidak mengkhususkan pada satu jenis kantor dengan alasan keterbatasan jumlah pegawai yang dapat ditemui untuk dijadikan responden karena kesibukan para pegawai tersebut. Kuisioner dalam penelitian ini menggunakan skala likert 1-5 untuk mengukur persepsi pegawai dengan memberikan pilihan jawaban.

\section{Definisi Operasional Variabel}

\section{Variabel Dependen}

Kecenderungan Fraud di sektor publik dalam penelitian ini merupakan persepsi pegawai mengenai kecurangan akuntansi yang terjadi di sektor publik. Fraud dapat diartikan sebagai sebagai penipuan yang disengaja, termasuk berbohong, mencuri, merekayasa, dan menggelapkan. Fraud itu sendiri secara umum merupakan suatu perbuatan melawan hukum yang dilakukan oleh orang-orang dari dalam dan atau luar organisasi, dengan maksud untuk mendapatkan keuntungan pribadi atau kelompoknya yang secara langsung merugikan pihak lain. Pengukuran kecenderungan fraud menggunakan enam item pertanyaan dengan tiga indikator yaitu kecurangan laporan keuangan, penyalahgunaan asset, dan korupsi.

\section{Variabel Independen}

Keadilan distributif adalah keadilan yang dirasakan oleh para individu individu berdasarkan imbalan yang diterima (Robbins \& Timothy, 2008). Terdapat 7 item pertanyaan yang digunakan untuk mengukur 4 Indikator. Indikator yang digunakan untuk mengukur variabel keadilan distributif seperti yang dikembangkan oleh (Colquitt, 2001) yaitu: 
1. Persamaan/kesetaraan : persepsi mengenai persamaan atau kesetaraan usaha dalam pekerjaan dengan imbalan yang diterima.

2. Kelayakan : persepsi mengenai kelayakan imbalan dengan penyelesaian pekerjaan.

3. Kontribusi : persepsi mengenai kesesuaian imbalan dengan kontribusi pada perusahaan.

4. Kinerja : persepsi mengenai kesesuaian antara kinerja dengan imbalan.

Keadilan prosedural adalah keadilan yang dirasakan individu terhadap proses penentuan distribusi imbalan (S. P. Robbins \& Timothy, 2008). Indikator keadilan prosedural menurut (Colquitt, 2001) yaitu kendali proses, kendali keputusan, konsistensi, bebas prasangka, akurasi Informasi.

Sistem pengendalian internal menggunakan lima indikator yang didasarkan pada unsur sistem pengendalian internal COSO (2004) dan PP nomor 60 tahun 2008 tentang SPI yaitu lingkungan pengendalian, penilaian resiko, kegiatan pengendalian, informasi dan komunikasi, pemantauan dan pengendalian internal.

Gaya kepemimpinan diukur dengan menggunakan indikator yang dikembangkan oleh Fiedler dalam (S. P. Robbins \& Timothy, 2008) yaitu relasi pimpinan dan bawahan, struktur tugas, posisi kekuatan, orientasi prestasi, kepemimpinan partisipatif. Budaya etis organisasi diukur dengan menggunakan indikator yang dikembangkan (Moeljono, 2003), yaitu hukuman bagi tindakan tidak etis, mekanisme perlindungan etika, model peran yang visibel, komunikasi harapan-harapan etis, pelatihan etika.

\section{HASIL PENELITIAN DAN PEMBAHASAN}

\section{Uji Validitas Konstruk}

Uji validitas konstruk diukur dengan parameter skor loading pada model penelitian (Rule of Thumbs > 0,7) menggunakan parameter skor loading dan skor AVE harus > 0,5. Pada penelitian ini hasil analisis menunjukkan skor loading konstruk ditunjukkan pada gambar berikut. 


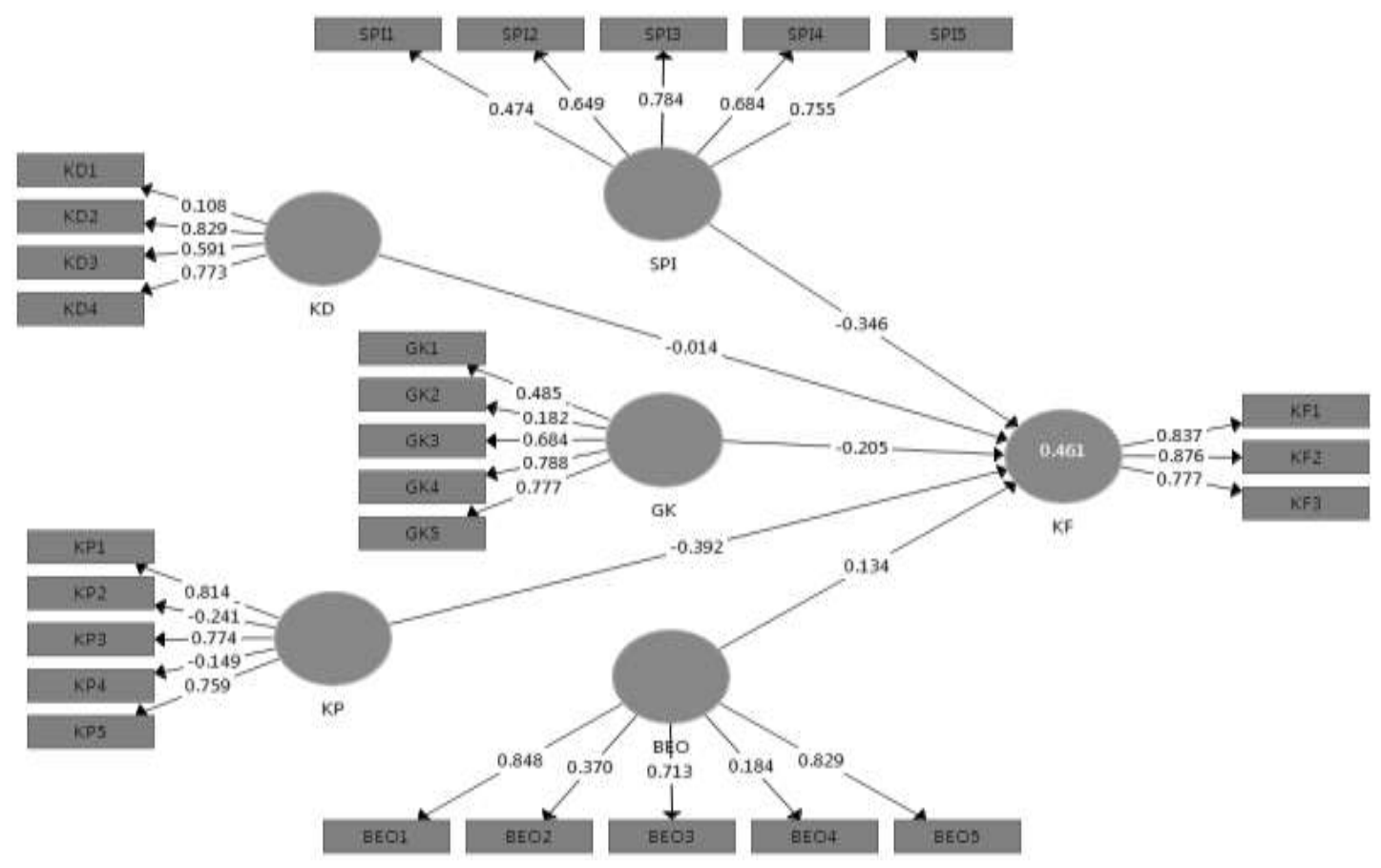

Gambar 1. Pengujian Pertama

Sumber: Data diolah 2020

Gambar 1 menunjukkan nilai konstruk Konstruk yang memiliki nilai di bawah imana nilai skor loading yang memenuhi 0,7 akan dihapus dari model sehingga syarat adalah (Rule of Thumbs > 0,7). menghasilkan model baru sebagai berikut.

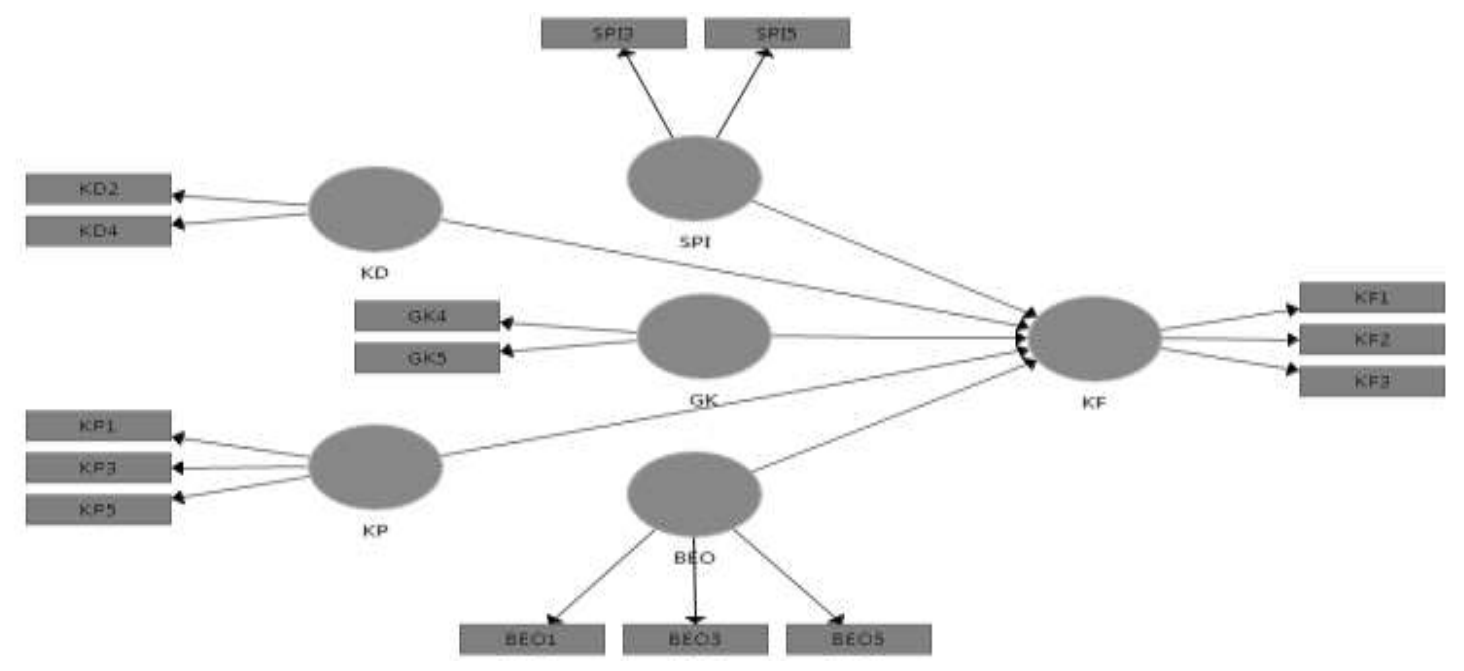

Gambar 2. Pengujian Pertama

Sumber: Data diolah 2020 


\section{Uji Convergent Validity}

Parameter uji validitas konvergen dilihat dari skor AVE dengan syarat masing-masing variabel harus bernilai di atas 0,5. Berdasarkan tabel 1 dibawah ini, Semua konstruk memiliki nilai AVE diatas 0,5. Hal ini berarti probabilitas indikator disuatu konstruk untuk masuk ke variabel lain lebih rendah (kurang dari 0,5) sehingga probabilitas indikator tersebut konvergen dan masuk pada konstruk yang ditujukan lebih besar yaitu diatas 50 persen.

Tabel 1

Uji Model

\begin{tabular}{lcccc}
\hline & $\begin{array}{c}\text { Cronbach's } \\
\text { Alpha }\end{array}$ & rho_A & $\begin{array}{c}\text { Composite } \\
\text { Reliability }\end{array}$ & $\begin{array}{c}\text { Average Variance } \\
\text { Extracted (AVE) }\end{array}$ \\
\hline $\begin{array}{l}\text { Budaya Etis } \\
\text { Organisasi }\end{array}$ & 0,759 & 0,768 & 0,862 & 0,677 \\
Gaya Kepemimpinan & 0,671 & 0,691 & 0,823 & 0,670 \\
Keadilan Distributif & 0,761 & 0,789 & 0,817 & 0,692 \\
Kecenderungan & 0,776 & 0,792 & 0,870 & 0,690 \\
Fraud & 0,711 & 0,712 & 0,838 & 0,633 \\
Keadilan Prosedural & 0,694 & 0,799 & 0,854 & 0,745 \\
SPI & & & &
\end{tabular}

Sumber: Data diolah 2020

\section{Uji Discriminant Validity}

Berdasarkan Tabel 1 dapat dilihat hasil discriminant validity yang menunjukkan nilai akar kuadrat AVE setiap konstruk lebih besar daripada nilai korelasi antara konstruk dengan konstruk lainnya dalam model, maka dikatakan memiliki nilai discriminant validity yang baik.

\section{Uji Reability}

Berdasarkan Tabel 1 menunjukan bahwa hasil Cronbach alfa dan composite reability menunjukan nilai yang memuaskan yaitu nilai masing-masing variabel diatas nilai minimum Cronbach alfa 0,6 dan nilai minimum composite reability 0,7 . Hal tersebut menunjukkan konsistensi dan stabilitas instrumen yang digunakan tinggi.

\section{Uji Inner Model}

\section{R-Square}

Pengujian inner model atau model struktural dilakukan untuk melihat hubungan antara konstruk, nilai signifikansi dan R-square dari model penelitian. 
Tabel 2

R-Square

\begin{tabular}{ccc}
\hline & R Square & R Square Adjusted \\
\hline Kecenderungan Fraud & 0,487 & 0,452 \\
\hline Sumber: Data diolah 2020 & &
\end{tabular}

Tabel 2 menunjukan bahwa nilai sedangkan $52 \%$ dijelaskan oleh variabel R-square Kecenderungan fraud di sektor lain di luar yang diteliti.

publik di kota Makassar sebesar 0,487.

Nilai R-square sebesar 0,487 memiliki arti

Uji Hipotesis

bahwa variabilitas Kecenderungan fraud

Hasil pengujian hipotesis dapat di sektor publik di kota Makassar dapat di dilihat pada output uji Path coeficient jelaskan oleh variabilitas konstruk KD, pada tabel berikut. KP, SPI, GK, dan BEO, sebesar $48 \%$

Tabel 3

Path coefficient

\begin{tabular}{cccccc}
\hline & $\begin{array}{c}\text { Original } \\
\text { Sample (O) }\end{array}$ & $\begin{array}{c}\text { Sample } \\
\text { Mean }(\mathbf{M})\end{array}$ & $\begin{array}{c}\text { Standard } \\
\text { Deviation }\end{array}$ & $\begin{array}{c}\text { T Statistics } \\
(\mathbf{O} / \text { STDEV) }\end{array}$ & P Values \\
\hline KD -> KF & $-0,083$ & $-0,087$ & 0,101 & 0,819 & 0,413 \\
KP -> KF & $-0,264$ & $-0,244$ & 0,125 & 2,114 & 0,035 \\
SPI -> KF & $-0,374$ & $-0,372$ & 0,099 & 3,779 & 0,000 \\
GK -> KF & $-0,229$ & $-0,239$ & 0,111 & 2,070 & 0,039 \\
BEO -> KF & $-0,021$ & $-0,001$ & 0,117 & 0,184 & 0,854 \\
\hline Sumber: Data diolah 2020 & & & &
\end{tabular}

Berdasarkan uji path coefficient berpengaruh terhadap kecenderungan pada Tabel 6, hasil pengujian fraud ditolak karena nilai t-statistik menunjukkan bahwa KD (keadilan sebesar $0,819<1,659$ dan nilai P-value distributif) dan BEO (budaya etis >0,05 yaitu 0,423. Hasil ini bertentangan organisasi) tidak berpengaruh terhadap dengan hasil penelitian penelitian Adinda kecenderungan fraud. T-statistik dan Ikhsan(2015).

menunjukkan nilai dibawah 1,659 dan P-

Hipotesis kedua yang menyatakan value yang menunjukkan nilai signifikansi keadilan prosedural berpengaruh negatif berada diatas 0,05. Hipotesis KD yang terhadap kecenderungan fraud diterima. menyatakan bahwa keadilan distributif Nilai t-statistik sebesar 2,114 lebih besar 
dari nilai t-tabel 1,96 dan nilai p-value $0,035<0,05$ serta koefisien -0,264. Data statistik menunjukkan bahwa keadilan prosedural berpengaruh negatif terhadap kecenderungan fraud. Hasil penelitian ini sesuai dengan penelitian Adinda dan Ikhsan (2015). Penelitian ini mendukung pendapat Greenberg dan Baron (2003) yang menyatakan keadilan prosedural merupakan persepsi keadilan atas pembuatan keputusan dalam organisasi. Orang-orang di dalam organisasi sangat memperhatikan dalam pembuatan keputusan secara adil sehingga mencegah orang-orang untuk berbuat kecurangan.

Hasil ini juga sesuai dengan opini (Palupi, 2013) bahwa keadilan tidak sekedar membandingkan input dan output tetapi pegawai melakukan identifikasi bagaimana proses dan prosedur dalam penentuan suatu outcome sehingga mencegah mereka berbuat kecurangan. Berdasarkan analisis dari alat uji, indikator yang berpengaruh dan menjadi ukuran konstruk adalah kendali proses, konsistensi, dan akurasi informasi. Ukuran ini dikembangkan oleh Colqiutt (2001).

Sistem pengendalian internal berpengaruh negatif terhadap kecenderungan fraud. Hasil menunjukkan hipotesis ketiga diterima. Semakin tinggi persepsi terhadap efektifitas SPI maka mengurangi kecenderungan kecurangan. Nilai signifikansi sebesar $0,000<0,05$ dan t-satatistik 3,779 serta koefisien 0,374 yang menunjukkan pengaruh negatif terhadap kecenderungan kecurangan. Hasil ini mendukung penelitian Pramudita (2013), Wilopo (2006), Adinda dan Ikhsan (2015), Faisal (2013), Puspasari dan Suwardi (2012). Indikator yang membentuk ukuran konstruk adalah kegiatan pengendalian dan pemantauan serta pengendalian internal. Indikator ini di kembangkan dari unsur sistem pengendalian internal COSO (2004).

Terdapat pengaruh negatif gaya kepemimpinan terhadap kecenderungan fraud pegawai yang bekerja disektor publik. Nilai t-statistik dan p-value menunjukkan nilai 2,070 dan 0,039 . Koefisien -0,299 menunjukkan arah hubungan yang negatif. Semakin tinggi persepsi terhadap gaya kepemimpinan maka kecenderungan kecurangan semakin menurun. Hasil ini sesuai dengan hasil penelitian Aditya (2013), dan COSO (2004) yang mengatakan bahwa lingkungan yang etis dari suatu organisasi meliputi gaya kepemimpinan dalam mencapai sasaran organisasitoris, nilainilai mereka dan gaya manajemen, 
menciptakan suatu lingkungan yang lebih etis, dan karyawan akan cenderung untuk mengikuti peraturan perusahaan sehinggah mengurangi kecurangan. Indikator yang digunakan dalam mengukur konstruk gaya kepemimpinan dikembangkan oleh Fiedler dalam Robbins (2010). Berdasarkan alat uji statistik, indikator yang membentuk konstruk adalah pemimpin yang berorientasi prestasi dan memiliki gaya kepemimpinan partisipatif.

\section{KESIMPULAN}

Hasil penelitian menunjukkan adanya pengaruh negatif variabel keadilan prosedural, sistem pengendalian internal dan gaya kepemimpinan terhadap kecenderungan kecurangan (fraud) pada pegawai yang bekerja di sektor publik di kota Makassar. Persepsi terhadap adanya keadilan prosedural menyebabkan orangorang didalam organisasi merasa adil dalam hal perlakuan perusahaan terhadap setiap individu. Adanya rasa keadilan inilah yang membuat berkurangnya kecenderungan kecurangan. Sistem pengendalian internal yang baik akan mencegah kecenderungan pegawai untuk melakukan kecurangan, karena sistem pegendalian yang baik akan membuat individu berpikir untuk berbuat kecurangan. Gaya kepemimpinan akan mencegah kecurangan karena persepsi pegawai terhadap pimpinan yang memiliki gaya kepemimpinan yang khas akan mengurangi pegawai melakukan kecurangan. Pemimpin yang partisipatif dan terbuka serta melibatkan pegawai secara luas serta berorientasi prestasi akan mencegah individu melakukan kecurangan.

Penelitian ini berkontribusi dalam pengembangan riset tentang topik fraud. Masalah nomor satu negara Indonesia adalah korupsi. Korupsi paling banyak terjadi di sektor publik. Berbagai tindakan yang dilakukan pemerintah sepertinya tidak berhasil dalam mengurangi tindak kecurangan (fraud) yang salah satunya adalah korupsi. Untuk penelitian selanjutnya masih banyak variabel yang mungkin berpengaruh terhadap kecenderungan individu untuk melakukan fraud. Mungkin juga ada hubungannya dengan koneksi politik, seperti yang kita ketahui bahwa rata-rata di Indonesia yang melakukan korupsi adalah orang yang memiliki jaringan politik.

\section{UCAPAN TERIMA KASIH}

Kami ucapkan banyak terima kasih kepada Direktorat Riset dan 
Pengabdian Masyarakat, Kemendikbud, Lembaga layanan dikti wilayah 9 Sulawesi dan STIE Tri Dharma Nusantara atas segala bantuan serta pendanaan pelaksanaan penelitian ini. Meskipun terjadi berbagai hambatan seperti bencana nasional Covid-19, namun dukungan pemerintah terhadap dunia pendidikan dan penelitian tidak pernah surut, semoga hasil penelitian ini dapat bermanfaat bagi dunia pendidikan

\section{DAFTAR PUSTAKA}

Betts, D. (2009). The Psychology of Fraud: What Makes Employee Cross The Line. ACFE Report.

Colquitt, J. A. (2001). On the dimensionality of organizational justice: a construct validation of a measure. Journal of Applied Psychology, 86(3), 386.

Cressey, D. R. (1953). Other people's money; a study of the social psychology of embezzlement.

Greenberg, J., \& Baron, R. A. (2003). Behaviour in Organisations, eighth (international) edition. Prentice Hall.

Ivancevich John, M., Robert, K., \& Matteson Michael, T. (2006). Perilaku dan Manajemen Organisasi. Erlangga, Jakarta.

Moeljono, D. (2003). Budaya korporat dan keunggulan korporasi. Elex Media Komputindo.
Palupi, S. (2012). Persoalan Psikologis Wanita Menopause. Jurnal AlRisalah, 12(1), 103-114.

Pramudita, A. (2013). Analisis Fraud di Sektor Pemerintahan Kota Salatiga. Accounting Analysis Journal, 2(1).

Puspasari, N., \& Suwardi, E. (2012). Pengaruh Moralitas Individu Dan Pengendalian Internal Terhadap Kecenderungan Kecurangan Akuntansi: Studi Eksperimen Pada Konteks Pemerintahan Daerah. [Yogyakarta]: Universitas Gadjah Mada.

Rae, K., \& Subramaniam, N. (2008). Quality of internal control procedures. Managerial Auditing Journal.

Rawls, J. (2009). A theory of justice. Harvard university press.

Robbins, P. (2003). Stephen. 2003. Perilaku Organisasi.

Robbins, S. P., \& Timothy, A. (2008). Judge. Organizational Behavior, 12th Ed. Jakarta: Salemba Empat.

Schminke, M., Ambrose, M. L., \& Noel, T. W. (1997). The effect of ethical frameworks on perceptions of organizational justice. Academy of Management Journal, 40(5), 1190-1207.

Setiawan, I., IP, S., \& Si, M. (2016). Mengikis Perilaku Korupsi Pada Birokrasi Pemerintahan. Jurnal Ilmu Pemerintahan Widya Praja, 42.

Thibaut, J., \& Walker, L. (1978). A theory of procedure. Calif. L. Rev., 66, 541. 
Tyler, T. R., \& Blader, S. L. (2003). The group engagement model: Procedural justice, social identity, and cooperative behavior. Personality and Social Psychology Review, 7(4), 349-361.

Walster, E., Walster, G. W., \& Berscheid, E. (1978). Equity: Theory and research.

Wilopo. (2006). Analisis Faktor-faktor yang Berpengaruh Terhadap Kecenderungan Kecurangan Akuntansi: Studi pada Perusahaan Publik dan Badan Usaha Milik Negara di Indonesia. The Indonesian Journal of Accounting Research, 9(3). 